\title{
How Much Is That In Dollars?: Costly International Downsizing
}

Monika Renard, Florida Gulf Coast University, USA

Kay Tracy, Tracy and Associates, USA

\begin{abstract}
Economic downturns can lead companies doing business internationally to cut costs by reducing staff and/or closing subsidiaries. Efficiency in downsizing can put people and capital to their most effective use. This exercise educates students about country differences in labor termination practices, costs, legal requirements for downsizing, and other issues.
\end{abstract}

Keywords: international management; human resources; downsizing; severance costs; student exercise

\section{INTRODUCTION}

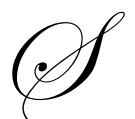

uccessfully operating as a multinational firm requires that a company be willing and able to reduce the number of employees or close a subsidiary when it is no longer viable. For example, Starbucks closed 977 stores worldwide from 2008 to 2009 (Allison, 2009), and Cerberus Capital Management closed their subsidiary in Hong Kong (Tucker \& Arnold, 2009). While closing subsidiaries can carry a host of different costs, those associated with the termination of employees can be both overlooked and underestimated.

Downsizing necessitates an understanding of global employment law and labor relations in various locations around the world. Often U.S. firms underestimate the difficulty and human resource costs of closing down an operation. This may be because the U.S. is one of the few countries in the world that still follows employmentat-will (ILO, 2010). In contrast, Siemens struck a deal with its union in Germany and promised employees jobs for life (Schäfer, 2010).

Many countries require a valid cause for termination of employment, e.g., Hong Kong, New Zealand. Others require governmental approval to fire workers, e.g., the Netherlands. Others require companies to consult with Workers' Councils or employees before closing operations, e.g. the Netherlands, New Zealand (ILO, 2010). Latin America is considered a region with a high level of labor regulations (Miranda-Munoz, 2007). Also, countries around the world have varying and often more expensive rules for terminations and reductions in force. Wages are only one part of the equation; companies must also understand the laws, prepare for legal costs and repercussions, and consider severance packages, notice requirements, and employee behaviors.

An important role for international human resource managers is to advise the strategic team charged with making downsizing or exit strategy decisions. To do so, all involved must understand and follow global employment laws and labor relations practices in the different locations. Laws and common labor practices covering operations around the world differ by country and are additionally influenced by such entities as the United Nations, World Bank, International Labour Organization, Organization for Economic Cooperation and Development, World Trade Organization, European Union, North America Free Trade Agreement, Mercosur, Association of South East Asian Nations, Arab Labour Organization, and The Delhi Declaration (Briscoe and Schuler, 2004).

Because students have little experience with international companies and legalities, this exercise was developed to help them understand and appreciate some global differences. The countries selected for this exercise reflect differences in business competitiveness and labor law practice. According to the Global Competitiveness Report 2010-11, of 139 countries ranked the U.S. is number four in competitiveness (Schwab, 2010). The other 
countries examined and their competitiveness scores are: Hong Kong $\left(11^{\text {th }}\right)$, the Netherlands $\left(8^{\text {th }}\right)$, New Zealand $\left(23^{\text {rd }}\right)$, Switzerland $\left(1^{\text {st }}\right)$, and Venezuela $\left(122^{\text {nd }}\right)$. That report also highlighted business executives' ranking of the most problematic factors for doing business in their country. Of those, "restrictive labor regulations" was ranked as $9^{\text {th }}$ in the U.S. The other countries' rankings were: Hong Kong $\left(2^{\text {nd }}\right)$, the Netherlands $\left(2^{\text {nd }}\right)$, New Zealand $\left(6^{\text {th }}\right)$, Switzerland $\left(3^{\text {rd }}\right)$, and Venezuela $\left(3^{\text {rd }}\right)$.

There is a great deal of information about staffing overseas subsidiaries with expatriates and the extensive costs involved, including repatriation. However, there is less information available about the costs associated with Host Country Nationals (HCN), and virtually none about the costs incurred when closing a subsidiary. These costs should be considered before decisions regarding staffing of overseas operations are made. This in-class exercise demonstrates the varying notice and severance costs associated with downsizing and closing subsidiaries staffed with HCNs in countries around the world. It educates students about country differences in labor termination practices and legal requirements for downsizing.

\section{THE EXERCISE}

\section{Goals}

The goals of this exercise include introducing students to the differences in severance costs and notice required to terminate workers and close subsidiaries in foreign countries. Additionally, students learn to consider possible discrimination and employee productivity changes connected to downsizing.

\section{Materials}

Instructors will need enough handouts for one per student consisting of the scenario and Table 1 (Employees in Your Subsidiary) and Table 2 (Country Termination Practices). Instructors will also need overheads for Table 3 (Computation Example, Termination Costs in the U.S.) and Table 4 (Total Termination Costs for Each Country), both for discussion purposes.

\section{EXERCISE PART 1}

\section{Directions}

For Part 1, divide the class into six groups and assign each group a country where their company subsidiary operates: U.S., Hong Kong, the Netherlands, New Zealand, Switzerland, or Venezuela. For larger classes, more groups can be formed and duplicate countries can be assigned. Then give out the exercise Customer Care Consultancy, which consists of the scenario, questions, and Tables 1 and 2. Have the students work with their groups to answer the questions in Part 1, allowing time for them to compute costs and discuss amongst themselves the answers to the questions, approximately 15 minutes. Then review the answers to questions 1-3 with the class.

\section{Discussion}

Students find this an enlightening and enjoyable exercise. Most of our students are from the U.S. and are accustomed to thinking in terms of employment-at-will, and so expect little difficulty or cost associated with closing down. They are surprised to discover that it can be expensive, and that laws vary around the world can curtail employers' actions. They are also surprised that costs to terminate employees are higher in other countries than in the U.S. Note that Switzerland, where business executives ranked restrictive labor regulations practices as $3^{\text {rd }}$ of 15 problematic business practices, has approximately five times the cost of closing a subsidiary in the U.S., where restrictive labor practices were ranked lower $\left(9^{\text {th }}\right.$ of 15$)$ (Schwab, 2010).

The information in Table 3 (Computational Example of Termination Costs in the U.S.) and Table 4 (Total Termination Costs for Each Country) are for your use to answer the student discussion questions 1 and 2 above. For question 3, students often bring up their concerns about what employees would do if they were told that they would lose their jobs after the notice period. Students wonder how productive employees would be, whether there would 
be wholesale absences, whether time on the job would be spent looking for other work, and other productivity concerns. Though not often mentioned, issues such as sabotage and fairness are brought forth. Depending on time, you may choose to discuss other comparative employment laws and practices that affect downsizing: works councils, non-compete agreements, discrimination, and others.

Note that Table 4 shows that restrictive labor practices in Venezuela, ranked as a major business obstacle by business executives, corresponds to the high cost of terminating operation. Also, in the U.S., where this was not considered to be one of the problematic factors, costs to close down an operation are considerably lower.

\section{EXERCISE PART 2}

\section{Directions}

For part 2, students should be asked to assume that their subsidiary is in the U.S. (show Table 3). Give them some time (approximately 5-10 minutes) to discuss the answers to questions 4 and 5 and then review their answers to those questions with the class.

\section{Discussion}

Student decisions to terminate are made on a variety of factors. Some rely on seniority, terminating the newer hires. Others base their decisions on costs, including high salary and/or high termination costs. Others take demographic information into consideration. And finally, some use a combination of criteria. Discussion can center around country differences in laws, relationships with labor, and/or attitudes toward discrimination.

Another discussion point is currency fluctuations' effect on costs. For example, the Hong Kong dollar is essentially fixed at $7.80 \mathrm{HKD}$ to $1 \mathrm{USD}$, whereas the Venezuelan Bolivar shows considerable fluctuation. Since HCNs are typically paid in local currency, the severance and notice costs can vary in conjunction with movements of the currency. For example, on January 11, 2010, the Venezuelan Bolivar's value against the U.S. dollar was 2.1446 and on January 12, 2010, it was 4.2893 (Federal Reserve, 2010). So if the Venezuelan subsidiary were closed on January 11 as opposed to January 12, the closure costs would be approximately doubled.

\section{CONCLUSIONS}

This in-class exercise demonstrates some differences in employment laws and practice around the world in relation to reducing staff and/or closing a subsidiary in a country. It highlights the importance of understanding the laws and practices in various countries for anyone interested in staffing international subsidiaries with HCNs. This in-class exercise is unique in that it examines issues and costs related to closing subsidiaries and gives students hands-on experience with computations and considerations of human resource issues.

\section{AUTHOR INFORMATION}

Dr. Monika Renard earned her Ph.D. in Human Resources from the University of Maryland. Dr. Renard is an Associate Professor at Florida Gulf Coast University, Fort Myers, FL where she teaches a wide variety of human resource topics, negotiation, and international management. Dr. Renard is also the Director of FGCU's Conflict Management Institute. Her research interests include human resources and international management.

Dr. Kay Blythe Tracy earned her Ph.D. in Organizational Behavior from the University of Maryland, College Park. She has taught there and at Gettysburg College, Gettysburg, PA. Dr. Tracy is currently affiliated with University of Maryland-University College, and does consulting work in Organizational Behavior for Lagniappe Unlimited in Sarasota, FL. Her research interests include entrepreneurship and international management. 


\section{REFERENCES}

1. Allison, Melissa. (2009). No more layoffs at Starbucks, Schultz says. Seattle Times. Published March 3, 2009. Accessed 10/2/10 from http://blog.seattletimes.nwsource.com/coffee/2009/03/03/no_more_layoffs_at_starbucks_s.html

2. Briscoe, D.R. and Schuler, R.S. (2004). International Human Resource Management. 2nd edition. London and NY: Routledge.

3. Dutch Government Answers for Business (2010). Accessed 10/2/10 from:

4. http://www.answersforbusiness.nl//product/permits/Ontslagvergunning?subject=165

5. Federal Reserve (2010). Federal Reserve Statistical Release September 27, 2010. Accessed 10/3/10 from http://www.federalreserve.gov/releases/h10/Hist/dat00_ve.htm

6. Hong Kong Tourism Board (2010). Published August 6, 2010. Accessed 10/2/10 from http://www.discoverhongkong.com/eng/trip-planner/hongkong-money.html

7. ILO (2000). Termination of employment digest: A legislative review. Geneva, International Labour Office. Accessed 10/2/10 from http://www.ilo.org/public/libdoc/ilo/2000/100B09 152_engl.pdf.

8. Miranda-Munoz, Martha. (2007). Social security and the labour market: A mismatch? Globalization and Protection against Unemployment Risk in the Americas. 5th International Research Conference on Social Security. Accessed 10/2/10 from: http://www.issa.int/esl/content/download/39476/771251/file/2miranda.pdf.

9. New Zealand Ministry of Economic Development (2010). Published June 21, 2010. Accessed 10/2/10 from http://www.business.govt.nz/companies/learn-about/closing-a-company/removing-a-company/overseascompany.

10. Schäfer, Daniel (2010). Siemens promises workers jobs for life. Financial Times, Published: September 22 2010. Accessed 10/2/2010 from http://www.ft.com/cms/s/0/591dc8a0-c68c-11df-8a9f-00144feab49a.html

11. Schwab, Klaus (2010). The Global Competitiveness Report 2010-2011 published by World Economic Forum. Accessed 10/1/10 from http://www3.weforum.org/docs/WEF_GlobalCompetitivenessReport_201011.pdf

12. Tucker, Sundeep \& Arnold, Martin (2009). Cerberus poised to close HK office. Financial Times. Published February 23, 2010. Accessed 10/2/10 from: http://www.ft.com/cms/s/0/a1df6874-0148-11de$\underline{8 \mathrm{f} 6 \mathrm{e}-000077 \mathrm{~b} 07658 . h \mathrm{html} \text { ?nclick check=1. }}$. 


\section{APPENDIX 1}

The Handout for Customer Care Consultancy

\section{Customer Care Consultancy}

Customer Care Consultancy (CCC) is a small multinational organization that specializes in providing customer service functions on an outsourcing basis for local businesses in various countries. CCC's competitive advantage is the extensive training they give each employee in "treating customers right" and conflict management skills to deal with difficult customers. $\mathrm{CCC}$ has a number of small subsidiaries located in the U.S., Hong Kong, the Netherlands, New Zealand, Switzerland, and Venezuela. Recently, because of local government unrest, they have decided to close down a subsidiary, even though they are currently quite profitable. CCC knows that there will be repercussions of this strategic decision and have asked you to advise them on what to do.

\section{Part 1}

Refer to Table 1 and Table 2 to answer the following questions. We will discuss your answers after you are done.

1. What must CCC do regarding their employees in order to close down the subsidiary legally? That is, what notice is required, if any? How long will CCC have to pay salaries until they can close down? What will be the cost of those salaries (individually and collectively) for that time?

2. What will this action cost CCC in terms of severance packages? That is, compute the cost for all of the employees in the location and determine the total cost to close the subsidiary. (CCC allows the maximum payment whenever an option exists.)

3. What other employee issues and concerns may CCC encounter?

Part 2

Congratulations, your U.S. subsidiary has been saved! Instead of closing down, your subsidiary will stay open with a reduced workforce. You must termination three employees. Assume that all the employees have similar performance appraisals and can do the basic work required. Answer the following discussion questions:

4. Whom will you terminate? Why?

5. What are the costs and other considerations for this decision?

Table 1: Employees in Your Subsidiary

\begin{tabular}{|l|c|c|c|c|l}
\hline \multicolumn{1}{|c|}{ Employee } & $\begin{array}{c}\text { Yrs. of } \\
\text { Service }\end{array}$ & $\begin{array}{c}\text { Yearly Salary } \\
\text { (U.S. equiv.) }\end{array}$ & $\begin{array}{c}\text { Monthly } \\
\text { Salary }\end{array}$ & $\begin{array}{c}\text { Weekly } \\
\text { Salary }\end{array}$ & \multicolumn{1}{c}{ Other } \\
\hline Armand Apunyo & 1 & $\$ 20,000$ & $1,666.67$ & 384.62 & Male, 35, married, 3 children \\
\hline Bailey Boven & 5 & $\$ 50,000$ & $4,166.67$ & 961.54 & Male, 45, married, 5 children \\
\hline Carla Chanda & 2 & $\$ 30,000$ & $2,500.00$ & 576.92 & Female, single, 1 child, disabled \\
\hline Danielo Dunizzio & 4 & $\$ 40,000$ & $3,333.33$ & 769.23 & Male, 55, divorced, 2 children \\
\hline Elka Ecctiok & 1 & $\$ 25,000$ & $2,083.33$ & 480.77 & Female, 25, married. \\
\hline Fabio Forte & 4 & $\$ 45,000$ & $3,750.00$ & 865.38 & Male, 42, married, 4 children \\
\hline Gwen Gurmish & 2 & $\$ 35,000$ & $2,916.67$ & 673.08 & Female, 26, pregnant, $1^{\text {st }}$ child \\
\hline Helga Hernandez & 2 & $\$ 22,000$ & $1,833.33$ & 423.08 & Female, 22, single, disabled \\
\hline Indira Iniquez & 3 & $\$ 33,000$ & $2,750.00$ & 634.62 & Female, 32, divorced, 2 children \\
\hline Jerry Joon & 4 & $\$ 44,000$ & $3,666.67$ & 846.15 & Male, 36, divorced, 1 child \\
\hline
\end{tabular}


Table 2: Country Termination Practices*

\begin{tabular}{|c|c|c|}
\hline Country & Notice requirements & Severance payment formula \\
\hline Hong Kong & $\begin{array}{l}\text { By agreement or no less than one month's } \\
\text { notice }\end{array}$ & $\begin{array}{l}\text { Payment required for employees with at least two years of } \\
\text { service. Two-thirds of one month's salary for each year of } \\
\text { service. }\end{array}$ \\
\hline Netherlands & $\begin{array}{l}\text { Notice or payment in lieu of notice: two } \\
\text { pay periods but not more than } 6 \text { weeks }\end{array}$ & $\begin{array}{l}\text { Payment varies by age and length of service; minimum one } \\
\text { month's salary for each year of service. }\end{array}$ \\
\hline New Zealand & $\begin{array}{l}\text { Company must wait three months after } \\
\text { giving public notice }\end{array}$ & $\begin{array}{l}\text { Negotiated between parties. Four weeks' salary for first year } \\
\text { of employment and two weeks for each additional year; no } \\
\text { legal minimum or maximum }\end{array}$ \\
\hline Switzerland & $\begin{array}{l}\text { Related to seniority, one month to three } \\
\text { months' notice }\end{array}$ & Two weeks to one month's salary for every year worked. \\
\hline United States & $\begin{array}{l}\text { None required for small companies, but } 2 \\
\text { weeks' pay in lieu of notice is common. } \\
\text { (The WARN law covers large companies } \\
\text { only.) }\end{array}$ & $\begin{array}{l}\text { No mandatory severance pay; minimum one week's pay for } \\
\text { each year of service is customary. }\end{array}$ \\
\hline Venezuela & $\begin{array}{l}\text { Notice requirements: after one month's } \\
\text { service--one week's notice; six months-- } \\
\text { two weeks; one year--one month; five } \\
\text { years--two months }\end{array}$ & $\begin{array}{l}\text { Thirty days' pay for each year of service; maximum payment } \\
\text { of } 150 \text { days' pay in cases of involuntary termination. }\end{array}$ \\
\hline
\end{tabular}

*Adapted from Briscoe and Schuler (2004) with updated information from: Financial Times (Schafer, 2010), country sources (New Zealand Ministry of Economic Development, 2010; Dutch Government Answers for Business, 2010; Hong Kong Tourism Board, 2010), Miranda-Munoz (2007), and the ILO (2010). 


\section{APPENDIX 2}

Tables for Discussion

Table 3: Computational Example, Termination Costs in the U.S.

\begin{tabular}{|l|c|c|c|c|c|c|}
\hline \multicolumn{1}{|c|}{ Employee } & $\begin{array}{c}\text { Yrs. of } \\
\text { Service }\end{array}$ & $\begin{array}{c}\text { Monthly } \\
\text { Salary }\end{array}$ & $\begin{array}{c}\text { Weekly } \\
\text { Salary }\end{array}$ & Notice & Severance & Total Costs \\
\hline Armand Apunyo & 1 & $\$ 1,666.67$ & $\$ 384.62$ & $\$ 769.24$ & $\$ 384.62$ & $\$ 1,153.86$ \\
\hline Bailey Boven & 5 & $4,166.67$ & 961.54 & $1,923.08$ & $4,807.70$ & $6,730.78$ \\
\hline Carla Chanda & 2 & $2,500.00$ & 576.92 & $1,153.84$ & $1,153.84$ & $2,307.68$ \\
\hline Danielo Dunizzio & 4 & $3,333.33$ & 769.23 & $1,538.46$ & $3,076.92$ & $4,615.38$ \\
\hline Elka Ecctiok & 1 & $2,083.33$ & 480.77 & 961.54 & 480.77 & $1,442.31$ \\
\hline Fabio Forte & 4 & $3,750.00$ & 865.38 & $1,730.76$ & $3,461.52$ & $5,192.28$ \\
\hline Gwen Gurmish & 2 & $2,916.67$ & 673.08 & $1,346.16$ & $1,346.16$ & $2,692.32$ \\
\hline Helga Hernandez & 2 & $1,833.33$ & 423.08 & 846.16 & 846.16 & $1,692.32$ \\
\hline Indira Iniquez & 3 & $2,750.00$ & 634.62 & $1,269.24$ & $1,903.86$ & $3,173.10$ \\
\hline Jerry Joon & 4 & $3,666.67$ & 846.15 & $1,692.30$ & $3,384.60$ & $5,076.90$ \\
\hline Totals in U.S. Dollars & & & & $\$ 13,230$ & $\$ 20,846$ & $\$ 34,076$ \\
\hline
\end{tabular}

We computed Tables 4-9 by using the data in Table 3 above and the instructions in the exercise.

Table 4: Total Termination Costs for Each Country

\begin{tabular}{|l|c|c|c|}
\hline \multicolumn{1}{|c|}{ Country } & Notice & Severance & Total Costs \\
\hline Hong Kong & $\$ 28,666.67$ & $\$ 57,722.23$ & $\$ 86,388.90$ \\
\hline Netherlands & $39,692.34$ & $90,333.35$ & $130,025.69$ \\
\hline New Zealand & $86,000.01$ & $54,923.08$ & $140,923.09$ \\
\hline Switzerland & $86,000.01$ & $90,333.35$ & $176,333.36$ \\
\hline U.S. & $13,230.78$ & $20,846.15$ & $34,076.93$ \\
\hline Venezuela & $\$ 32,833.34$ & $\$ 198,461.70$ & $\$ 231,295.04$ \\
\hline
\end{tabular}

Table 5: Computational Example, Termination Costs in Hong Kong

\begin{tabular}{|l|c|c|c|c|c|c|}
\hline \multicolumn{1}{|c|}{ Employee } & $\begin{array}{c}\text { Yrs. of } \\
\text { Service }\end{array}$ & $\begin{array}{c}\text { Monthly } \\
\text { Salary }\end{array}$ & $\begin{array}{c}\text { Weekly } \\
\text { Salary }\end{array}$ & Notice & Severance & Total Costs \\
\hline Armand Apunyo & 1 & $\$ 1,666.67$ & $\$ 384.62$ & $\$ 1,666.67$ & $\$ 0$ & $\$ 1,666.67$ \\
\hline Bailey Boven & 5 & $4,166.67$ & 961.54 & $4,166.67$ & $13,888.90$ & $18,055.57$ \\
\hline Carla Chanda & 2 & $2,500.00$ & 576.92 & $2,500.00$ & $3,333.33$ & $5,833.33$ \\
\hline Danielo Dunizzio & 4 & $3,333.33$ & 769.23 & $3,333.33$ & $8,888.88$ & $12,222.21$ \\
\hline Elka Ecctiok & 1 & $2,083.33$ & 480.77 & $2,083.33$ & 0 & $2,083.33$ \\
\hline Fabio Forte & 4 & $3,750.00$ & 865.38 & $3,750.00$ & $10,000.00$ & $13,750.00$ \\
\hline Gwen Gurmish & 2 & $2,916.67$ & 673.08 & $2,916.67$ & $3,888.89$ & $6,805.56$ \\
\hline Helga Hernandez & 2 & $1,833.33$ & 423.08 & $1,833.33$ & $2,444.44$ & $4,277.77$ \\
\hline Indira Iniquez & 3 & $2,750.00$ & 634.62 & $2,750.00$ & $5,500.00$ & $8,250.00$ \\
\hline Jerry Joon & 4 & $3,666.67$ & 846.15 & $3,666.67$ & $9,777.79$ & $13,444.46$ \\
\hline Totals in U.S. Dollars & & & & $\$ 28,666.67$ & $\$ 57,722.23$ & $\$ 86,388.90$ \\
\hline
\end{tabular}


Table 6: Computational Example, Termination Costs in the Netherlands

\begin{tabular}{|l|c|c|c|c|c|c|}
\hline \multicolumn{1}{|c|}{ Employee } & $\begin{array}{c}\text { Yrs. of } \\
\text { Service }\end{array}$ & $\begin{array}{c}\text { Monthly } \\
\text { Salary }\end{array}$ & $\begin{array}{c}\text { Weekly } \\
\text { Salary }\end{array}$ & Notice & Severance & Total Costs \\
\hline Armand Apunyo & 1 & $\$ 1,666.67$ & $\$ 384.62$ & $\$ 2,307.72$ & $\$ 1,666.67$ & $\$ 3,974.39$ \\
\hline Bailey Boven & 5 & $4,166.67$ & 961.54 & $5,769.24$ & $20,833.35$ & $26,602.59$ \\
\hline Carla Chanda & 2 & $2,500.00$ & 576.92 & $3,461.52$ & $5,000.00$ & $8,461.52$ \\
\hline Danielo Dunizzio & 4 & $3,333.33$ & 769.23 & $4,615.38$ & $13,333.32$ & $17,948.70$ \\
\hline Elka Ecctiok & 1 & $2,083.33$ & 480.77 & $2,884.62$ & $2,083.33$ & $4,967.95$ \\
\hline Fabio Forte & 4 & $3,750.00$ & 865.38 & $5,192.28$ & $15,000.00$ & $20,192.28$ \\
\hline Gwen Gurmish & 2 & $2,916.67$ & 673.08 & $4,038.48$ & $5,833.34$ & $9,871.82$ \\
\hline Helga Hernandez & 2 & $1,833.33$ & 423.08 & $2,538.48$ & $3,666.66$ & $6,205.14$ \\
\hline Indira Iniquez & 3 & $2,750.00$ & 634.62 & $3,807.72$ & $8,250.00$ & $12,057.72$ \\
\hline Jerry Joon & 4 & $3,666.67$ & 846.15 & $5,076.90$ & $14,666.68$ & $19,743.58$ \\
\hline Totals in U.S. Dollars & & & & $\$ 39,692.34$ & $\$ 90,333.35$ & $\$ 130,025.69$ \\
\hline
\end{tabular}

Table 7: Computational Example, Termination Costs in New Zealand

\begin{tabular}{|l|c|c|c|c|c|c|}
\hline \multicolumn{1}{|c|}{ Employee } & $\begin{array}{c}\text { Yrs. of } \\
\text { Service }\end{array}$ & $\begin{array}{c}\text { Monthly } \\
\text { Salary }\end{array}$ & $\begin{array}{c}\text { Weekly } \\
\text { Salary }\end{array}$ & Notice & Severance & Total Costs \\
\hline Armand Apunyo & 1 & $\$ 1,666.67$ & $\$ 384.62$ & $\$ 5,000.01$ & $\$ 1,538.48$ & $\$ 6,538.49$ \\
\hline Bailey Boven & 5 & $4,166.67$ & 961.54 & $12,500.01$ & $11,538.48$ & $24,038.49$ \\
\hline Carla Chanda & 2 & $2,500.00$ & 576.92 & $7,500.00$ & $3,461.52$ & $10,961.52$ \\
\hline Danielo Dunizzio & 4 & $3,333.33$ & 769.23 & $9,999.99$ & $7,692.30$ & $17,692.29$ \\
\hline Elka Ecctiok & 1 & $2,083.33$ & 480.77 & $6,249.99$ & $1,923.08$ & $8,173.07$ \\
\hline Fabio Forte & 4 & $3,750.00$ & 865.38 & $11,250.00$ & $8,653.80$ & $19,903.80$ \\
\hline Gwen Gurmish & 2 & $2,916.67$ & 673.08 & $8,750.01$ & $4,038.48$ & $12,788.49$ \\
\hline Helga Hernandez & 2 & $1,833.33$ & 423.08 & $5,499.99$ & $2,538.48$ & $8,038.47$ \\
\hline Indira Iniquez & 3 & $2,750.00$ & 634.62 & $8,250.00$ & $5,076.96$ & $13,326.96$ \\
\hline Jerry Joon & 4 & $3,666.67$ & 846.15 & $11,000.01$ & $8,461.50$ & $19,461.51$ \\
\hline Totals in U.S. Dollars & & & & $\$ 86,000.01$ & $\$ 54,923.08$ & $\$ 140,923.09$ \\
\hline
\end{tabular}

Table 8: Computational Example, Termination Costs in Switzerland

\begin{tabular}{|l|c|c|c|c|c|c|}
\hline \multicolumn{1}{|c|}{ Employee } & $\begin{array}{c}\text { Yrs. of } \\
\text { Service }\end{array}$ & $\begin{array}{c}\text { Monthly } \\
\text { Salary }\end{array}$ & $\begin{array}{c}\text { Weekly } \\
\text { Salary }\end{array}$ & Notice & Severance & Total Costs \\
\hline Armand Apunyo & 1 & $\$ 1,666.67$ & $\$ 384.62$ & $\$ 5,000.01$ & $\$ 1,666.67$ & $\$ 6,666.68$ \\
\hline Bailey Boven & 5 & $4,166.67$ & 961.54 & $12,500.01$ & $20,833.35$ & $33,333.36$ \\
\hline Carla Chanda & 2 & $2,500.00$ & 576.92 & $7,500.00$ & $5,000.00$ & $12,500.00$ \\
\hline Danielo Dunizzio & 4 & $3,333.33$ & 769.23 & $9,999.99$ & $13,333.32$ & $23,333.31$ \\
\hline Elka Ecctiok & 1 & $2,083.33$ & 480.77 & $6,249.99$ & $2,083.33$ & $8,333.32$ \\
\hline Fabio Forte & 4 & $3,750.00$ & 865.38 & $11,250.00$ & $15,000.00$ & $26,250.00$ \\
\hline Gwen Gurmish & 2 & $2,916.67$ & 673.08 & $8,750.01$ & $5,833.34$ & $14,583.35$ \\
\hline Helga Hernandez & 2 & $1,833.33$ & 423.08 & $5,499.99$ & $3,666.66$ & $9,166.65$ \\
\hline Indira Iniquez & 3 & $2,750.00$ & 634.62 & $8,250.00$ & $8,250.00$ & $16,500.00$ \\
\hline Jerry Joon & 4 & $3,666.67$ & 846.15 & $11,000.01$ & $14,666.68$ & $25,666.69$ \\
\hline Totals in U.S. Dollars & & & & $\$ 86,000.01$ & $\$ 90,333.35$ & $\$ 176,333.36$ \\
\hline
\end{tabular}


Table 9: Computational Example, Termination Costs in Venezuela

\begin{tabular}{|l|c|c|c|c|c|c|c|}
\hline \multicolumn{1}{|c|}{ Employee } & $\begin{array}{c}\text { Yrs. of } \\
\text { Service }\end{array}$ & $\begin{array}{c}\text { Monthly } \\
\text { Salary }\end{array}$ & $\begin{array}{c}\text { Weekly } \\
\text { Salary }\end{array}$ & $\begin{array}{c}\text { daily } \\
(\mathbf{w k l y} / \mathbf{5})\end{array}$ & $\begin{array}{c}\text { Notice } \\
\text { (monthly) }\end{array}$ & Severance & Total Costs \\
\hline Armand Apunyo & 1 & $\$ 1,666.67$ & $\$ 384.62$ & $\$ 76.92$ & $\$ 1,666.67$ & $\$ 11,538.60$ & $\$ 13,205.27$ \\
\hline Bailey Boven & 5 & $4,166.67$ & 961.54 & 192.31 & $8,333.34$ & $28,846.20$ & $37,179.54$ \\
\hline Carla Chanda & 2 & $2,500.00$ & 576.92 & 115.38 & $2,500.00$ & $17,307.60$ & $19,807.60$ \\
\hline Danielo Dunizzio & 4 & $3,333.33$ & 769.23 & 153.85 & $3,333.33$ & $23,076.90$ & $26,410.23$ \\
\hline Elka Ecctiok & 1 & $2,083.33$ & 480.77 & 96.15 & $2,083.33$ & $14,423.10$ & $16,506.43$ \\
\hline Fabio Forte & 4 & $3,750.00$ & 865.38 & 173.08 & $3,750.00$ & $25,961.40$ & $29,711.40$ \\
\hline Gwen Gurmish & 2 & $2,916.67$ & 673.08 & 134.62 & $2,916.67$ & $20,192.40$ & $23,109.07$ \\
\hline Helga Hernandez & 2 & $1,833.33$ & 423.08 & 84.62 & $1,833.33$ & $12,692.40$ & $14,525.73$ \\
\hline Indira Iniquez & 3 & $2,750.00$ & 634.62 & 126.92 & $2,750.00$ & $19,038.60$ & $21,788.60$ \\
\hline Jerry Joon & 4 & $3,666.67$ & 846.15 & 169.23 & $3,666.67$ & $25,384.50$ & $29,051.17$ \\
\hline Totals in U.S. Dollars & & & & & $\$ 32,833.34$ & $\$ 198,461.70$ & $\$ 231,295.04$ \\
\hline
\end{tabular}


NOTES 